\title{
THE STABILIZATION OF VANCOMYCIN BY PEPTIDOGLYCAN ANALOGS
}

\author{
Constance M. Harris, Hana Kopecka and Thomas M. Harris \\ Department of Chemistry, Vanderbilt University, \\ Nashville, Tennessee 37235, USA
}

(Received for publication May 26, 1984)

\begin{abstract}
The glycopeptide antibiotic vancomycin is unstable in solution. It undergoes a rearrangement involving the conversion of an asparagine residue to isoaspartate to give an antibiotically inactive species, CDP-I. Peptide analogs of bacterial peptidoglycan, such as Ac-DAla-D-Ala and di-Ac-L-Lys-D-Ala-D-Ala bind to vancomycin and stabilize the antibiotic against degradation and consequent loss of activity. Protection by peptide is effective even under prolonged heating at $80^{\circ} \mathrm{C}$ or steam sterilization $\left(30\right.$ minutes, $\left.10^{4} \mathrm{~kg} / \mathrm{m}^{2}\right)$.
\end{abstract}

Vancomycin (1), a glycopeptide antibiotic elaborated by Streptomyces orientalis is used clinically for treatment of methicillin-resistant Staphylococcus aureus infections and Clostridium difficile-induced colitis ${ }^{1 \sim 3}$. The structure of this relatively large (MW 1,447) natural product has interested chemists since its isolation in $1956^{4 \sim 8)}$, although only recently was the structure fully defined. Structure elucidation was hindered by failure of the antibiotic to give crystals suitable for analysis by X-ray crystallography, but eventually a crystal structure was obtained for CDP-I, an antibiotically inactive hydrolysis product of the antibiotic ${ }^{7)}$. CDP-I was subsequently shown by WiLLIamson and WiLliams ${ }^{8)}$ to exist in two forms, major (CDP-I-M, 2) with the chlorine on ring 2 on the front or concave side of the molecule and minor (CDP-I-m, 3) with the chlorine on the back or convex side, as it is in vancomycin. Formation of CDP-I was initially believed to involve simple hydrolysis of an isoasparagine residue to an isoaspartate but work in our laboratory ${ }^{9)}$ subsequently showed that a rearrangement of the peptide

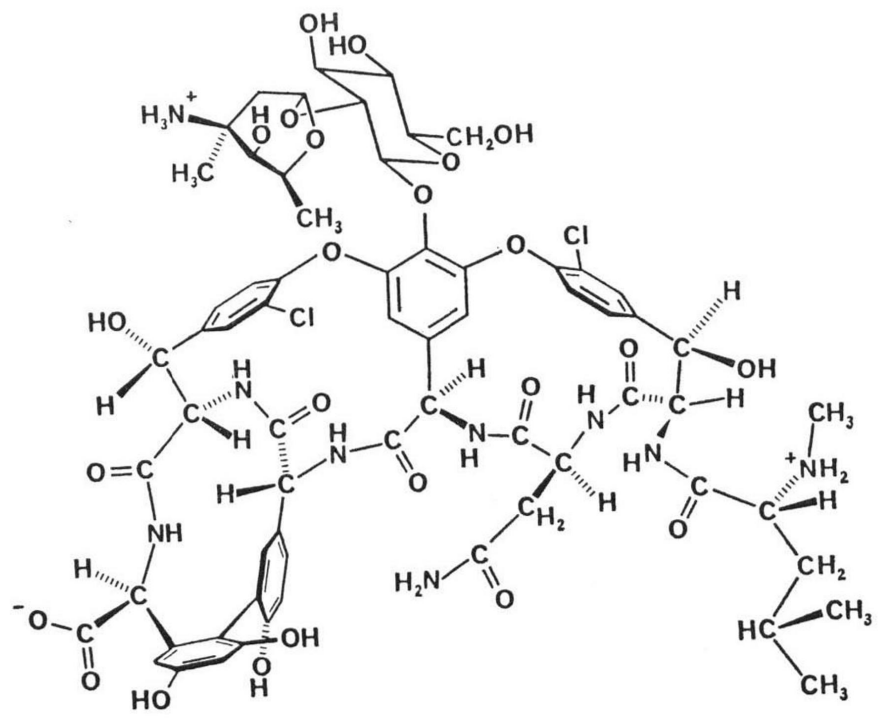




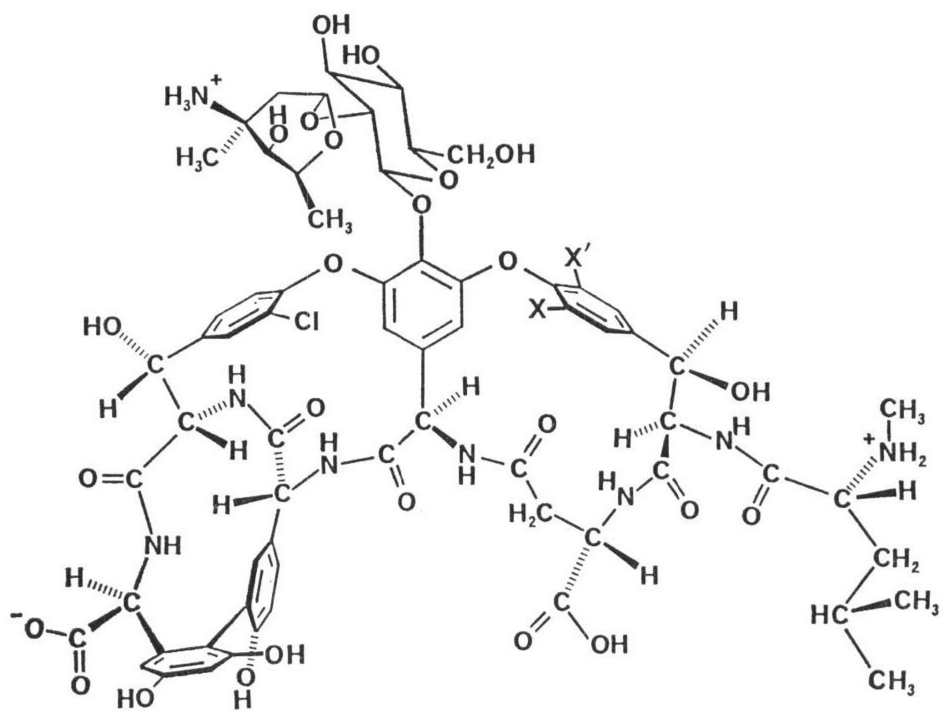

$$
\begin{aligned}
& 2 \mathrm{X}=\mathrm{Cl}, \mathrm{X}^{\prime}=\mathrm{H} \\
& 3 \mathrm{X}=\mathrm{H}, \mathrm{X}^{\prime}=\mathrm{Cl}
\end{aligned}
$$

backbone was occurring in which an asparagine residue rearranged via a cyclic imide to an isoaspartate. The rearrangement expands the cyclophane ring in which residue 2 is embedded so that the aromatic ring of residue 2 can rotate to bring the chloro substituent to the front side of the antibiotic, leading to an equilibrium mixture of the major and minor forms of CDP-I (approximately $2: 1$ at $25^{\circ} \mathrm{C}$ ), hereafter referred to as CDP-I. Two incorrect structures for vancomycin were proposed before this rearrangement was discovered ${ }^{7,8)}$. Although there are a number of other antibiotics, such as ristocetin, actinoidin, avoparcin, A35512B, the actaplanins and teichomycin $\mathrm{A}_{2}$ which are closely related, vancomycin is the only one known to contain an asparagine.

Conversion of vancomycin into CDP-I is a facile process which occurs near neutrality and at rates much higher than those for hydrolysis of simple amides or normal peptide linkages. Indeed, unique structural features of the vancomycin molecule must play a key role in the rearrangement because the reaction has not been observed in other asparagine-containing peptides and proteins under similar reaction conditions. The instability of vancomycin is of interest to clinicians as well as organic chemists because the drug must be stored in dry form although aqueous solutions are employed for oral and intravenous administration. Even with refrigeration, solutions have been reported to have limited shelf lives $^{10,11)}$.

We now report that certain peptides which complex with vancomycin inhibit CDP-I formation. Studies of the mechanism of action of vancomycin have revealed its ability to complex with peptide constituents of bacterial peptidoglycan ${ }^{12,13)}$. In the early 1970's, prior to significant structural information being available about vancomycin, NIETO and PERKINS ${ }^{14)}$ mapped out many of the structural features of peptides necessary for complex formation with the antibiotic. The binding process was initially studied by ultraviolet difference spectroscopy; more recently high field NMR using measurements of nuclear Overhauser effects and chemical shift changes has been employed to identify the peptide binding 
site in the antibiotic ${ }^{15 \sim 20)}$. On the basis of these studies, Williams et al. ${ }^{19)}$ have proposed a model of the peptide binding process which rationalizes much of the peptide affinity data which is now available.

\section{Results and Discussion}

In our first experiment, three aqueous samples of vancomycin (1 mM, pH 4.2) were stored at room temperature. Stoichiometric quantities of Ac-D-Ala-D-Ala (4) and di-Ac-L-Lys-D-Ala-D-Ala (5) were added to two of the samples while the remaining one served as a control. After three months, the solutions were assayed by HPLC. Whereas the control had undergone $20 \%$ conversion to CDP-I, essentially no rearrangement had occurred in the samples to which the peptides had been added.
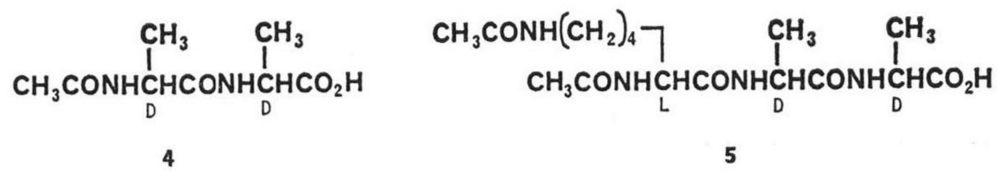

Next a more detailed study was made at $80^{\circ} \mathrm{C}$ using solutions which had been adjusted to $\mathrm{pH} 6.0$. Table 1 shows that $50 \%$ of the vancomycin in the control sample had rearranged to CDP-I whereas only $23 \%$ decomposition had occurred in the presence of one equivalent of dipeptide 4 . Two equivalents of the dipeptide were more effective, reducing the observed decomposition to only $8 \%$.

Although no difference was detected at room temperature, tripeptide 5 provides more effective protection at $80^{\circ} \mathrm{C}$ than the dipeptide. Only $10 \%$ degradation was observed in the presence of a stoichiometric quantity of tripeptide and, with two equivalents of $\mathbf{5}$, no degradation was observed. On the other hand, only slight protection was provided by Ac-D-Ala-Gly or by Ac-Gly-DAla; $39 \%$ and $28 \%$ decomposition was observed in the presence of stoichiometric quantities of the respective peptides in $1 \mathrm{~mm}$ solutions. AcD-Ala- $\beta$-Ala and Ac-D-Ala-aminoisobutyric acid provided no discernible protection.

The degree of protection by these peptides correlates well with the binding affinities of the peptides for the antibiotic; values of the association constants reported by NiETo and PERKINS ${ }^{14)}$ are tabulated in Table 1 for the four peptides that showed varying amounts of protection.

Table 1. Stabilization of vancomycin by aliphatic peptides.

\begin{tabular}{lcc}
\hline \multicolumn{1}{c}{ Peptide added } & $\begin{array}{c}\% \text { Degra- } \\
\text { dation }\end{array}$ & $\mathrm{K}_{\text {association }}$ \\
\hline None & 50 & - \\
Di-Ac-L-Lys-D-Ala-D-Ala & & \\
$\quad(1: 1)$ & 10 & $1.5 \times 10^{6}$ \\
Di-Ac-L-Lys-D-Ala-D-Ala & & \\
$\quad(2: 1)$ & 0 & $" \prime$ \\
Ac-D-Ala-D-Ala $(1: 1)$ & 23 & $2.0 \times 10^{4}$ \\
Ac-D-Ala-D-Ala $(2: 1)$ & 8 & $" \prime$ \\
Ac-D-Ala-Gly $(1: 1)$ & 39 & $5.4 \times 10^{3}$ \\
Ac-Gly-D-Ala $(1: 1)$ & 28 & $1.1 \times 10^{4}$ \\
Ac-D-Ala- $\beta$-Ala & 50 & $<10^{3}$ \\
Ac-D-Ala-aminoisobutyric acid & 50 & $<10^{3}$ \\
\hline
\end{tabular}

Solutions $(2 \mathrm{ml})$ contained vancomycin $(1.0 \mathrm{~mm})$ and peptide in the indicated ratio in $0.05 \mathrm{~m}$ potassium phosphate buffer, $\mathrm{pH}$ 6.0. The samples were heated at $80^{\circ} \mathrm{C}$ for 20 hours and then analyzed for vancomycin, CDP-I-M and CDP-I-m by HPLC (Altex C-18 column, elution with $13.5 \% \mathrm{CH}_{3} \mathrm{CN}$ $0.1 \%$ TFA, $3 \mathrm{ml} / \mathrm{minute})$.

The other two peptides exhibited very weak binding when UV difference titrations were carried out in the manner described by those workers.

These results demonstrate definitively the ability of the binding peptides to inhibit CDP-I formation. The procedure would have value for stabilizing vancomycin solutions if it does not interfere with antibiotic activity. A test of this question was made with dipeptide $\mathbf{4}$ using vancomycin solutions 
Table 2. Protection of antibiotic activity by Ac-D-Ala-D-Ala.

\begin{tabular}{lcc}
\hline \multicolumn{1}{c}{ Sample } & \% Degradation & \% Antibiotic activity \\
\hline Vancomycin-unheated & 0 & 100 \\
Vancomycin-heated & 63 & 25 \\
Vancomycin+Ac-D-Ala-D-Ala $(1: 2)$ unheated & 0 & 100 \\
Vancomycin+Ac-D-Ala-D-Ala $(1: 2)$ heated & 13 & 87 \\
\hline
\end{tabular}

Solutions $(2 \mathrm{ml})$ contained vancomycin $(1 \mathrm{~mm})$ and peptide $(2 \mathrm{~mm})$ at an initial $\mathrm{pH}$ of 4.40 . Heating was carried out for 66 hours at $80^{\circ} \mathrm{C}$. Analysis for degradation was carried out by HPLC (Altex or IBM C-18 column, gradient elution with $7.75 \% \mathrm{CH}_{3} \mathrm{CN}-0.1 \mathrm{M}$ ammonium formate (pH 6.05) to $18.75 \% \mathrm{CH}_{3} \mathrm{CN}$ $0.1 \mathrm{~m}$ ammonium formate ( $\mathrm{pH} 6.20), 2 \mathrm{ml} / \mathrm{minute})$. Antibiotic activity was assayed by disc diffusion on agar using $B$. subtilis as the test organism.

Table 3. Protection of vancomycin by peptides under steam sterilization conditions.

\begin{tabular}{lc}
\hline \multicolumn{1}{c}{ Additive } & $\begin{array}{c}\% \text { Antibiotic } \\
\text { activity }\end{array}$ \\
\hline None & 58 \\
Ac-D-Ala-D-Ala $(1: 1)$ & 70 \\
Ac-D-Ala-D-Ala & \\
$(2: 1$, peptide: antibiotic) & 81 \\
Di- $N$-Ac-L-Lys-D-Ala-D-Ala & \\
$(1: 1)$ & 98 \\
\hline
\end{tabular}

Solutions contained vancomycin (1 mM) and peptide in the indicated ratio, initial $\mathrm{pH} 4.2 \sim 4.3$. They were steam sterilized for 30 minutes at $10^{4}$ $\mathrm{kg} / \mathrm{m}^{2}$ and then assayed for antibiotic activity by disc diffusion on agar. that had been heated at $80^{\circ} \mathrm{C}$ for 66 hours (see Table 2). Under these conditions, HPLC analysis indicated $63 \%$ conversion of a $1 \mathrm{~mm}$ solution of vancomycin to CDP-I; antibiotic assay with Bacillus subtilis showed that only $25 \%$ of the antibiotic activity remained. In the presence of two equivalents of dipeptide 4 , only $13 \%$ degradation occurred, as measured by HPLC and loss of activity. With unheated controls, with and without dipeptide, no CDP-I formation could be detected nor was any loss of antibiotic activity observed. On one hand the dipeptide is effective in stabilizing the antibiotic while on the other it does not inhibit antibiotic activity, even though both processes probably involve the same binding site on the antibiotic. The explanation for this paradoxical result is that the thermal degradation studies were conducted with solutions $(1 \mathrm{mM})$ which were sufficiently concentrated so that most of the vancomycin was present in the bound form. The association constant shown in Table 1 was measured at $25^{\circ} \mathrm{C}$; binding constants decrease with temperature and a value of $4 \times 10^{3}$ can be estimated for dipeptide 4 at $80^{\circ} \mathrm{C}$. Thus approximately $60 \%$ of the vancomycin would be expected to be in the bound form at $80^{\circ} \mathrm{C}$. For the antibiotic assay these solutions were diluted by a factor of 20 to 200 leading to substantial dissociation of the peptide complex even at room temperature. Furthermore, the dipeptide represents only a portion of the structure of the cellular receptors for the antibiotic and as a consequence probably has a lower affinity for the antibiotic than does the natural substrate.

As a final experiment, peptide protection was evaluated (see Table 3) under conditions of steam sterilization $\left(10^{4} \mathrm{~kg} / \mathrm{m}^{2}, 121^{\circ} \mathrm{C}\right)$. Again using $1 \mathrm{~mm}$ solutions, extensive loss of antibiotic activity (42\%) occurred during 30 minutes of heating the antibiotic in the absence of peptide. Dipeptide 4 provided only partial protection, affording 70 and $81 \%$ retention of antibiotic activity after heat treatment using 1 and 2 equivalents of dipeptide. The decreased effectiveness of dipeptide reflects a higher rate of decomposition coupled with a lower affinity constant at that temperature. It is noteworthy that with tripeptide 5, which binds vancomycin somewhat more efficiently (estimated $\mathrm{K}_{\mathrm{Association}}$ at $121^{\circ} \mathrm{C}: 1.2 \times$ $\left.10^{4}\right)^{13)}$, no loss of antibiotic activity was observed.

The mechanism of CDP-I formation involves cyclization of the asparagine residue by attack of the C-1 amide nitrogen on the C-4 carbonyl group to give a cyclic imide which cleaves by water attack ex- 
Fig. 1. Rearrangement of vancomycin to CDP-I.

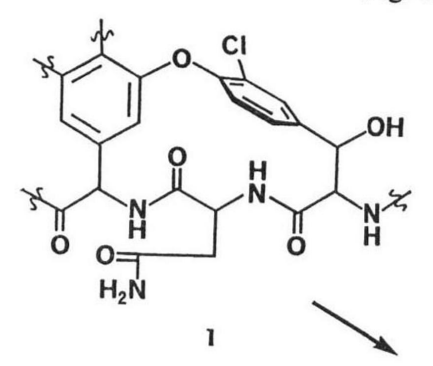

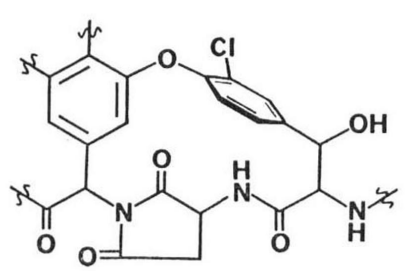<smiles>CCNC(O)C(NC)C(=O)NC(CC(=O)NC(C(C)=O)c1ccc(Oc2ccccc2)c(Cl)c1)C(=O)O</smiles>

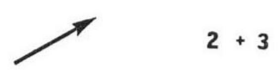

clusively at the C-1 carbonyl group to leave an isoaspartate residue in the peptide chain (Fig. 1). The process by which peptides $\mathbf{4}$ and $\mathbf{5}$ complex with vancomycin has been postulated to involve hydrogen bonding of the carboxylate anion of the peptide to a nest of NH groups as shown in Fig. $2^{7,18 \sim 20)}$. The cluster is made up of the terminal ammonium ion and the NH groups of the first three peptide bonds, i.e., the nest includes both peptide linkages of the asparagine residue but not the 4 carboxamide. The resulting nested structure is sterically incompatible with imide formation both when bonded to peptide and when free. Cyclic imide is formed from a more extended conformation. The imide is not capable of binding peptide, not just because one NH hydrogen bonding site ras been lost but because the extended conformation places the remaining carboxylate pocket too far from the receptor sites on the other end of the antibiotic molecule, so that the peptide is unable to complex simultaneously to both ends. Consequently, to the extent that free vancomycin is in equilibrium with bound material, succinimide formation can occur followed by irreversible ring opening.

\section{Experimental}

Vancomycin was obtained from Eli Lilly and used without further purification. Ac-D-Ala-D-Ala (4), di-Ac-L-Lys-D-Ala-D-Ala (5), Ac-D-Ala-Gly, and Ac-Gly-D-Ala were prepared according to NiETo and PERKINN ${ }^{14)}$. Ac-D-Ala-aminoisobutyric acid and Ac-D-Ala- $\beta$-Ala were prepared by similar methodology.

Ac-D-Ala- $\beta$-Ala: $\quad$ MP; $133.5 \sim 134.5^{\circ} \mathrm{C}$ (EtOH - hexane).

Anal Calcd for $\mathrm{C}_{8} \mathrm{H}_{14} \mathrm{~N}_{2} \mathrm{O}_{4}$ : C 47.52, H 6.98.

Found: $\quad \mathrm{C} 47.75, \mathrm{H} 7.12$.

$[\alpha]_{\mathrm{D}}^{23}+52^{\circ}(c 0.54, \mathrm{MeOH}) .{ }^{1} \mathrm{H}$ NMR $\left(90 \mathrm{MHz}, \mathrm{MeOH}-d_{4}\right) \delta 4.27(1 \mathrm{H}, \mathrm{q}, J=8 \mathrm{~Hz}), 3.41(2 \mathrm{H}, \mathrm{t}, J=$ $7 \mathrm{~Hz}), 2.49(2 \mathrm{H}, \mathrm{t}, J=7 \mathrm{~Hz}), 1.95(3 \mathrm{H}, \mathrm{s}), 1.30(3 \mathrm{H}, \mathrm{d}, J=8 \mathrm{~Hz})$.

Ac-D-Ala-aminoisobutyric Acid: MP; $163 \sim 164.5^{\circ} \mathrm{C}$ (EtOH - hexane).

Anal Calcd for $\mathrm{C}_{9} \mathrm{H}_{10} \mathrm{~N}_{2} \mathrm{O}_{4}$ : C 49.99, $\mathrm{H} 7.46$.
Found:
C $50.00, \mathrm{H} 7.32$.

$[\alpha]_{\mathrm{D}}^{23}+74^{\circ}(c 0.5, \mathrm{MeOH}),{ }^{1} \mathrm{H}$ NMR $\left(90 \mathrm{MHz}, \mathrm{MeOH}-d_{4}\right) \delta 4.32(1 \mathrm{H}, \mathrm{q}, J=8 \mathrm{~Hz}), 1.95(3 \mathrm{H}, \mathrm{s}), 1.48$ $(3 \mathrm{H}, \mathrm{s}), 1.46(3 \mathrm{H}, \mathrm{s}), 1.30(3 \mathrm{H}, \mathrm{d}, J=8 \mathrm{~Hz})$.

Solutions containing antibiotic or antibiotic plus peptide were adjusted to the desired $\mathrm{pH}$, placed in screw-capped culture tubes $(16 \times 125 \mathrm{~mm})$ with Teflon-lined caps and heated in a Reacti-Therm block (Pierce Chemical Company). If precipitate was present at the end of the heating period, $10 \mu 1$ of trifluoroacetic acid was added before HPLC analysis.

HPLC analysis was carried out either with a Spectra Physics Model 8700 system or an IBM Model 9533 ternary gradient liquid chromatograph with detection at $254 \mathrm{~nm}$. C-18 columns (Altex or IBM, 
Fig. 2. Proposed structure of vancomycin-peptide complex.

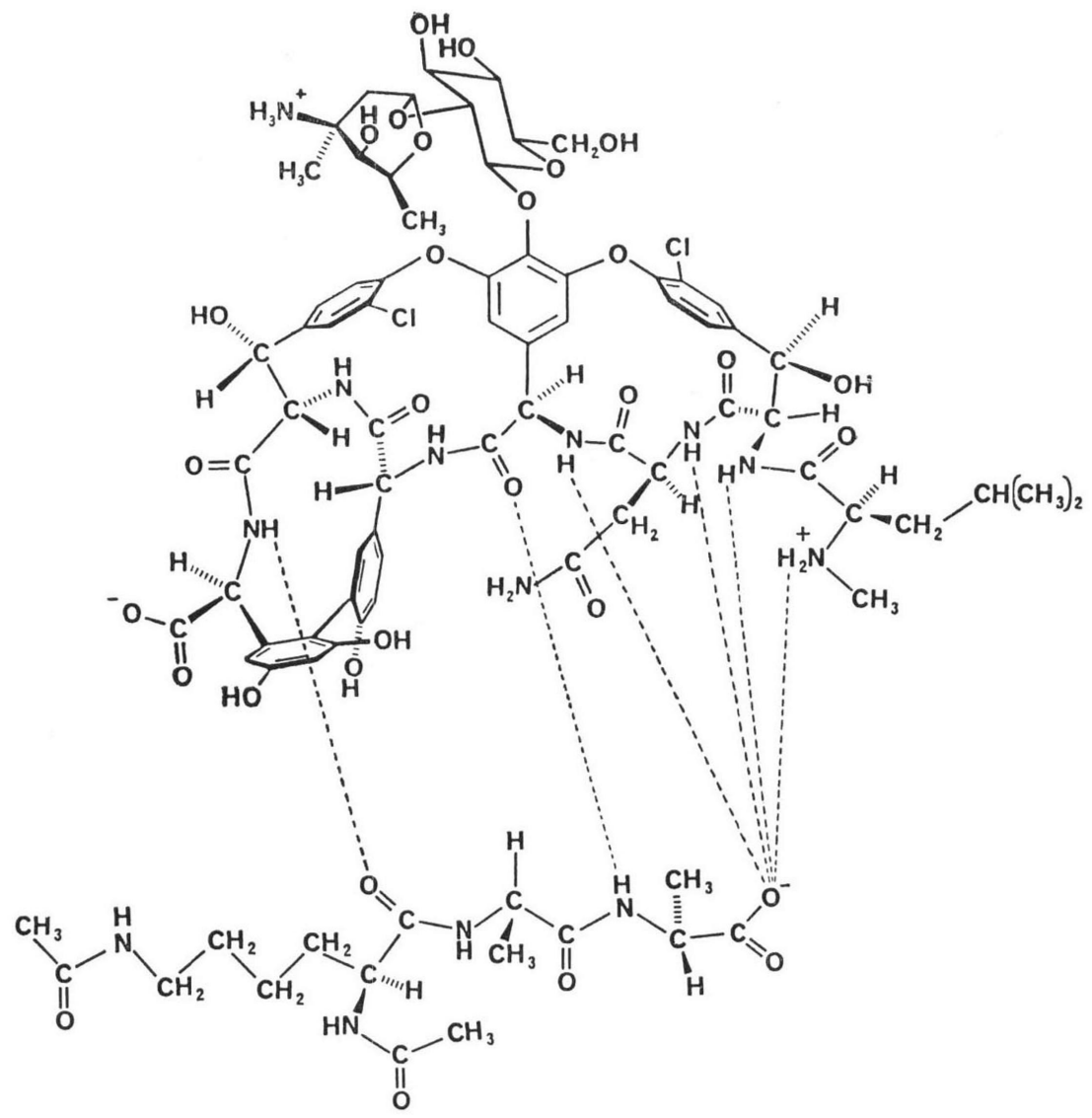

$4 \times 250 \mathrm{~mm}$ ) were used for analyses reported in Table 2. Gradient elution was performed using $7.75 \%$ $\mathrm{CH}_{3} \mathrm{CN}-0.1 \mathrm{M}$ ammonium formate ( $\mathrm{pH} 6.05$ ) to $18.75 \% \mathrm{CH}_{3} \mathrm{CN}-0.1 \mathrm{M}$ ammonium formate ( $\mathrm{pH}$ 6.20) over 15 minutes, $2 \mathrm{ml} /$ minute. Subsequently it was found that use of an Altex C-18 column $(10 \times$ $250 \mathrm{~mm}$ ) with elution by $13.5 \% \mathrm{CH}_{3} \mathrm{CN}-0.1 \%$ TFA gave superior resolution and more satisfactory integration, although the first separation system was adequate for the experiment described. Integration was carried out gravimetrically. For the purposes of this paper only peaks corresponding to vancomycin, CDP-I-M and CDP-I-m were evaluated. The \% vancomycin was calculated as:

and the $\%$ degradation:

$$
\% \text { Vancomycin }=\frac{\text { Vancomycin }}{\text { Vancomycin }+ \text { CDP-I-M }+ \text { CDP-I-m }} \times 100
$$

$$
\% \text { Degradation }=\frac{\% \text { Vancomycin in reaction mixture }}{\% \text { Vancomycin in standard }}
$$

HPLC analysis of the commercial vancomycin preparation used in these experiments indicated a $9 \%$ contamination by CDP-I species. Other more minor constituents were present, none greater than $5 \%$. Several of these were tentatively identified as mono- and didechlorovancomycin and their CDPtype rearrangement products by HPLC comparison with authentic samples. These were ignored in the present studies.

Antibiotic assays were carried out by the disc diffusion method ${ }^{21,22)}$ with B. subtilis (Difco) as the test organism. Assays were run in triplicate with each plate containing four concentrations of unknown and four of a standard vancomycin solution $(66 \mu \mathrm{g} / \mathrm{ml}$ to $6.6 \mu \mathrm{g} / \mathrm{ml})$. A graph of the diameter of inhibition zone vs. $\ln (\mathrm{c})$ was plotted and the concentration of unknown needed to produce an inhibition zone of $16 \mathrm{~mm}$ was measured. The $\%$ antibiotic activity is defined as: 


$$
\begin{gathered}
\% \text { Antibiotic activity }=\frac{\text { Concentration of vancomycin for } 16 \mathrm{~mm} \text { zone }}{\text { Concentration of unknown for } 16 \mathrm{~mm} \text { zone }} \times 100 \\
\text { Acknowledgments }
\end{gathered}
$$

We thank K. RAJAMOORTHI for the determination of binding constants for Ac-D-Ala- $\beta$-Ala and Ac-D-Alaaminoisobutyric acid and the U.S. Public Health Service for generous financial support (grant No. GM-23593).

\section{References}

1) Fekety, R.: Vancomycin. Med. Clin. North Am. 66: 175 181, 1982

2) Geraci, J. E. \& P. E. Hermans: Vancomycin. Mayo Clinic Proc. 58: 88 91, 1983

3) McHenry, M. C. \& T. L. Gavan: Vancomycin. Ped. Clin. North Am. 30: 31 47, 1983

4) McCormick, M. H.; W. M. Stark, G. E. Pittenger, R. C. Pittenger \& J. M. McGuire: Vancomycin, a new antibiotic. I. Chemical and biological properties. Antibiot. Ann. 1955/1956: 606 611, 1956

5) Williams, D. H.; V. Rajananda, M. P. Williamson \& G. Bojesen: The vancomycin and ristocetin group of antibiotics. Top. Antibiotic Chem. 5: 119 158, 1980

6) Perkins, H. R.: Vancomycin and related antibiotics. Pharmacol. Ther. 16: 181 197, 1982

7) Sheldrick, G. M.; P. G. Jones, O. Kennard, D. H. Williams \& G.A. Smith: Structure of vancomycin and its complex with acetyl-D-alanyl-D-alanine. Nature (London) 271: 223 225, 1978

8) Williamson, M. P. \& D. H. Williams: Structure revision of the antibiotic vancomycin. The use of nuclear Overhauser effect difference spectroscopy. J. Am. Chem. Soc. 103: 6580 6585, 1983

9) HARRIS, C. M.; H. KopeCKa \& T. M. HARRIS: Vancomycin: Structure and transformation to CDP-I. J. Am. Chem. Soc. 105: 6915 6922, 1983

10) Mallet, L.; G. P. Sesin, J. Ericson \& D. G. Fraser: Storage of vancomycin oral solution. N. Engl. J. Med. 307: 445, 1982

11) Mann, J. M.; D. L. Coleman \& J. C. Boylan: Stability of parenteral solutions of sodium cephalothin, cephaloridine, potassium penicillin G (buffered) and vancomycin hydrochloride. Am. J. Hosp. Pharm. 28: $760 \sim 763,1971$

12) Perkin, H. R.: Specificity of combination between mucopeptide precursors and vancomycin or ristocetin. Biochem. J. 111: 195 205, 1969

13) Nieto, M. \& H. R. Perkins: Physicochemical properties of vancomycin and iodovancomycin and their complexes with diacetyl-L-lysyl-D-alanyl-D-alanine. Biochem. J. 123: 773 787, 1971

14) Nieto, M. \& H. R. Perkins: Modifications of the acyl-D-alanyl-D-alanine terminus affecting complexformation with vancomycin. Biochem. J. 123: 789 803, 1971

15) Brown, J. P.; L. Terenius, J. Feeney \& A. S. V. Burgen: A structure-activity study by nuclear magnetic resonance of peptide interactions with vancomycin. Mol. Pharmacol. 11: 126 132, 1975

16) Brown, J. P.; J. Feeney \& A. S. V. Burgen: A nuclear magnetic resonance study of the interaction between vancomycin and acetyl-D-alanyl-D-alanine in aqueous solution. Mol. Pharmacol. 11: 119 125, 1975

17) Convert, O.; A. Bongini \& J. Feeney: A ${ }^{1} \mathrm{H}$ nuclear magnetic resonance study of the interactions of vancomycin with $N$-acetyl-D-alanyl-D-alanine and related peptides. J. Chem. Soc. Perkin Trans II 1980: $1262 \sim 1270,1980$

18) Williams, D. H. \& D. W. Butcher: Binding site of the antibiotic vancomycin for a cell-wall peptide analogue. J. Am. Chem. Soc. 103: 5697 5700, 1981

19) Williams, D. H.; M. P. Williamson, D. W. Butcher \& S. J. Hammond: Detailed binding sites of the antibiotics vancomycin and ristocetin A: Determination of intermolecular distances in antibiotic/substrate complexes by use of the time-dependent NOE. J. Am. Chem. Soc. 105: 1332 1339, 1983

20) Williamson, M. P.; D. H. Williams \& S. J. Hammond: Interactions of vancomycin and ristocetin with peptides as a model for protein binding. Tetrahedron 40:569 577, 1984

21) Coller, B. S. \& H. R. Gralnick: Studies on the mechanism of ristocetin-induced platelet agglutination. J. Clin. Invest. 60: 302 312, 1977

22) Crossley, K. B.; J. C. Rotschafer, M. M. Cherry, K. E. Mead \& D. E. Zaske: Comparison of a radioimmunoassay and a microbiological assay for measurement of serum vancomycin concentrations. Antimicrob. Agents Chemother. 17: 654 657, 1980 